\title{
Potensi Propolis Sebagai Imunomodulator Pada Tikus (Rattus norvegicus Berkenhout, 1769) Galur Wistar yang diinduksi Penisilin-G
}

\author{
LAKSMINDRA FITRIA ${ }^{1}$, ONNY NURRAHMAN MARWAYANA ${ }^{2}$ \\ ${ }^{1}$ Laboratorium Fisiologi Hewan, Fakultas Biologi, Universitas Gadjah Mada \\ ${ }^{2}$ Alumnus Fakultas Biologi, Universitas Gadjah Mada \\ Jl. Teknika Selatan, Sekip Utara, Sleman, Yogyakarta 55281 \\ email: laksmindraf@ugm.ac.id
}

\begin{abstract}
Propolis is a honeybee product collected from plants sap. This resinous substance is used to build and maintain the nest. Propolis has long been declared as a safe material for health maintaining. The purpose of this research was to study the potential use of Propolis as an immunomodulator in Penicillin-G-induced Wistar rats. A total of 30 male rats aged 5 months with 200-240 grams body weight were divided into 6 groups: Control Placebo (im injection of aquabidest+oral administration of $\mathrm{NaCl} 0.9 \%$ ); Control Penicillin (im injection of $21.6 \mathrm{mg}$ Penicillin+oral administration of $\mathrm{NaCl}$ 0.9\%); Control Propolis (im injection of aquabidest+oral administration of $27.0 \mathrm{mg}$ Propolis); Treatment 1 (im injection of $21.6 \mathrm{mg}$ Penicillin+oral administration of $13.5 \mathrm{mg}$ Propolis); Treatment 2 (im injection of $21.6 \mathrm{mg}$ Penicillin+oral administration of $27.0 \mathrm{mg}$ Propolis); and Treatment 3 (im injection of $21.6 \mathrm{mg}$ Penicillin+oral administration of $40.5 \mathrm{mg}$ Propolis). Leukocytes profile (total and differential counts), body temperature, and urine acidity $(\mathrm{pH})$ before and after treatment were determined as pretest and posttest data. Data were analyzed statistically using ANOVA followed by DMRT ( $\mathrm{p}<0.05$ ). Results showed that administration of Propolis significantly increased neutrophils count above the normal range (more than $4.41 \times 10^{3} / \mu \mathrm{L}$ ), whereas significantly decreased lymphocytes count below the normal range (less than $6.75 \times 10^{3} / \mu \mathrm{L}$ ). This causes the value of $\mathrm{N} / \mathrm{L}$ ratio increased significantly. Administration of Penicillin and the combination with Propolis significantly increased body temperature (above $38^{\circ} \mathrm{C}$ ), while treatment with Propolis alone did not induce fever or inflammation (normal temperature $37-38^{\circ} \mathrm{C}$ ). Administration of Propolis reduced urine acidity due to the impact of the administration of Penicillin ( $\mathrm{pH}$ 5.5-7.0). It can be concluded that oral administration of Propolis in Penicillin G-induced male Wistar rats exhibited immunosuppressive effect on lymphocytes. It was suggested as the role of Caffeic acid phenethyl ester (CAPE), the main bioactive compound in Propolis which also acts as an antiinflammatory agent. Further research is still needed to support this finding.
\end{abstract}

Keywords: CAPE, immune system, immunomodulators, Penicillin, Propolis

\section{PENDAHULUAN}

Propolis merupakan zat resin yang berasal dari cairan pepohonan, dikumpulkan oleh lebah madu (Apis mellifera L.) untuk membangun dan memelihara sarangnya. Propolis telah diakui manfaatnya sebagai bahan pemelihara kesehatan dan obat alami yang aman sejak zaman Yunani dan Romawi kuno atau sekitar tahun 300 SM (Omene et al., 2013). Propolis mengandung berbagai senyawa kimia seperti flavonoid, asam fenolat dan esternya, terpenoid, steroid, dan asamasam amino. Caffeic Acid Phenethyl Ester (CAPE) adalah senyawa bioaktif utama dalam
Propolis yang memegang peranan penting dalam pertahanan tubuh karena berpotensi sebagai antibakteri, antivirus, antifungi, antioksidan, antiinflamasi, antikanker, dan imunomodulator (Omene et al., 2013). Senyawa fenolik ini potensial dalam menghambat proliferasi sel $\mathrm{T}$, produksi limfokin, dan aktivasi NF-кB (Márquez et al., 2004).

Imunomodulator adalah suatu substansi yang mampu memodifikasi aktivitas sistem imun, baik dengan cara meningkatkan ataupun menekan respons imun melalui mekanisme tertentu. Modulasi dapat dipicu oleh infeksi 
antigen atau diinduksi oleh tubuh sendiri sehingga mempengaruhi proliferasi dan aktivasi sel-sel imunokompeten, produksi sitokin dan molekul-molekul sebagai mediator dan efektor (Yadav et al., 2015). Efek imunomodulasi dapat bekerja melalui dua cara, yaitu: efek imunostimulasi (meningkatkan respons imun) atau sebaliknya, efek imunosupresi (menekan respons imun).

Tikus (Rattus norvegicus Berkenhout, 1769) adalah salah satu hewan coba yang paling banyak digunakan sebagai model dalam penelitian biomedik (Johnson, 2012 dalam Fitria dan Sarto, 2014). Tikus Galur Wistar terus dibiakkan hingga kini karena ideal sebagai model penelitian praklinik untuk berbagai tujuan (River, 1998 dalam Fitria dan Sarto, 2014). Meskipun mudah dipelihara dan ditangani, namun tak jarang tikus laboratorium terinfeksi bakteri di berbagai sistem organnya. Hewan yang terinfeksi bakteri tampak normal dan sehat, tidak menunjukkan gejala klinis, karena efek infeksi tidak dapat langsung diamati. Uji mikrobiologi, serologi, dan rangkaian program pemantauan kesehatan berkala harus dilakukan disertai interpretasi dari pihak yang kompeten untuk menjelaskan status kesehatan hewan yang akan digunakan dalam penelitian. Hal ini tentu saja memakan waktu, tenaga, dan biaya.

Untuk memastikan hewan uji bebas dari infeksi bakteri, maka dilakukan antisipasi dengan antibiotika. Salah satu antibiotika yang paling sering diaplikasikan sebagai antibakteri adalah Penisilin-G. Tujuan, dosis, dan metode administrasi antibiotika yang tidak tepat dapat menimbulkan efek samping, antara lain: urtikaria, kerusakan organ, ketidakseimbangan mikroflora, respons imun seperti alergi dan hipersensitivitas, resistensi, hingga kematian. Penelitian ini bertujuan untuk mempelajari potensi Propolis sebagai imunomodulator pada tikus Wistar yang diinjeksi Penisilin-G.

\section{METODE}

Preparasi dan administrasi bahan uji. Bahan uji berupa Propolis (P.T. Cahya Sejahtera) dan Penisilin-G sodium atau Benzyl-penicillin (P.T. Meiji Indonesia Pharmaceutical Industries). Formulasi dosis
Propolis dan Penisilin diperoleh dengan cara konversi dosis manusia ke tikus menurut Purwanto dkk. (1992) dan Wijayanti dkk. (2003):

Dosis Propolis untuk manusia adalah 1,5 gram. Setelah dikonversi ke tikus dosis tersebut menjadi 27,0 mg. Propolis dilarutkan dalam garam fisiologis atau $\mathrm{NaCl} 0,9 \%$ (P.T. Otsuka Pharmaceutical Industries) hingga diperoleh 3 variasi dosis: $13,5 \mathrm{mg}$ ( $0,5 \mathrm{x}$ dosis); 27,0 mg (1,0x dosis); dan 40,5 mg (2x dosis). Propolis diberikan per oral dengan volume 1 $\mathrm{mL}$ (single dose).

Dosis Penisilin untuk manusia adalah $1,2 \times 10^{6}$ IU atau setara dengan 1,2 gram. Setelah dikonversi ke tikus dosis tersebut menjadi 21,6 mg. Penisilin dilarutkan dalam akuabides (P.T. Ikapharmindo Putramas Pharmaceutical Laboratories) hingga diperoleh dosis 21,6 mg. Penisilin diberikan dengan cara injeksi intramuskular (im) dengan volume $0,2 \mathrm{~mL}$ di tungkai belakang (single dose). Propolis dan/atau Penisilin diadministrasikan setelah tikus dipuasakan selama 4 jam, ditentukan sebagai jam ke-0. Penelitian diakhiri pada jam ke-4 (periode akut).

Pemeliharaan dan pengelompokan hewan uji. Hewan uji berupa 30 ekor tikus putih Galur Wistar umur 5 bulan dengan rerata berat badan 200-240 gram yang diperoleh dari LPPT-UGM Unit IV. Pemeliharaan dan perlakuan hewan uji dilakukan di "Rumah Tikus" Fakultas Biologi UGM dengan telah diupayakan mengikuti standar pemeliharaan hewan coba, mulai dari pengandangan, suplai pakan dan air minum, suhu ruangan, kelembapan, pencahayaan, tingkat kebisingan, dan sanitasi (Carlsson, 2008).

Hewan uji dibagi secara acak menjadi 6 kelompok yang terdiri atas 3 kelompok kontrol dan 3 kelompok perlakuan seperti disajikan dalam Tabel 1.

Pengambilan data. Sebelum penelitian dimulai, hewan diaklimasi selama satu minggu. Pemeriksaan dilakukan untuk memastikan tidak ada urtikaria, reaksi alergi/ hipersensitivitas, dan bentuk-bentuk respons imun lain yang menandakan hewan dalam kondisi sehat. Setelah perlakuan Penisilin 
dan/atau Propolis, kondisi tersebut kembali diamati kemudian dibandingkan dengan kondisi awal sebelum perlakuan. Selanjutnya dilakukan pengambilan data untuk memperoleh kisaran nilai awal/normal (baseline), meliputi: profil leukosit (jumlah total dan diferensial), suhu badan, dan $\mathrm{pH}$ urin.

Tabel 1. Matriks pengelompokan hewan uji dan perlakuan yang diberikan

\begin{tabular}{ccccc}
\hline Kelompok & $\begin{array}{c}\text { Injeksi im } \\
\text { akuabides }\end{array}$ & $\begin{array}{c}\text { Injeksi im } \\
\text { Penisilin }\end{array}$ & $\begin{array}{c}\text { Administrasi } \\
\text { per oral NaCl } \\
\mathbf{0 , 9 \%}\end{array}$ & $\begin{array}{c}\text { Administrasi } \\
\text { per oral } \\
\text { Propolis }\end{array}$ \\
\hline Kontrol Plasebo & $\checkmark$ & - & $\checkmark$ & - \\
\hline Kontrol Penisilin & - & $21,6 \mathrm{mg}$ & $\checkmark$ & - \\
\hline Kontrol Propolis & $\checkmark$ & - & - & $27,0 \mathrm{mg}$ \\
\hline Perlakuan 1 & - & $21,6 \mathrm{mg}$ & - & $13,5 \mathrm{mg}$ \\
\hline Perlakuan 2 & - & $21,6 \mathrm{mg}$ & - & $27,0 \mathrm{mg}$ \\
\hline Perlakuan 3 & - & $21,6 \mathrm{mg}$ & - & $40,5 \mathrm{mg}$ \\
\hline
\end{tabular}

Sampel darah untuk penentuan profil leukosit diambil dari sinus orbitalis setelah hewan dianestesi menggunakan Ketamin dosis $50 \mathrm{mg} / \mathrm{kg}$ BB. Sampel darah ditampung dalam microtube yang telah diberi EDTA, dilakukan penghitungan jumlah total dan diferensial leukosit menggunakan metode flowcytometry di laboratorium klinik. Pengambilan data berikutnya dilakukan setelah 4 jam perlakuan (kondisi akut). Berdasarkan data jumlah neutrofil dan limfosit kemudian ditentukan nilai rasio neutrofil/limfosit (rasio N/L). Suhu badan diukur menggunakan termometer klinis sebelum perlakuan (jam ke-0) dan setelah perlakuan (jam ke-4) untuk mengamati ada tidaknya peningkatan suhu sistemik (demam) yang menandakan adanya respons fisiologis dan imunologis terhadap perlakuan yang diberikan, yaitu Penisilin dan/atau Propolis.

Derajat keasaman $(\mathrm{pH})$ urin diukur menggunakan kertas indikator universal, dilakukan sebelum perlakuan (jam ke-0); 4 jam setelah dipuasakan; 4 jam setelah perlakuan Penisilin dan/atau Propolis; dan berikutnya setiap jam hingga $\mathrm{pH}$ urin kembali normal atau mendekati $\mathrm{pH}$ baseline.

Tabel 2. Profil fisiologis normal hewan uji yang digunakan dalam penelitian ini

\begin{tabular}{ccc}
\hline Variabel & Nilai & Persentase \\
\hline Berat badan & $200-240$ gram & \\
Total leukosit & $10,50-18,00 \times 10^{3} / \mu \mathrm{L}$ & \\
Neutrofil & $0,98-4,41 \times 10^{3} / \mu \mathrm{L}$ & $9,3-24,5 \%$ \\
Limfosit & $6,75-14,09 \times 10^{3} / \mu \mathrm{L}$ & $64,3-78,3 \%$ \\
Eosinofil & $0-0,41 \times 10^{3} / \mu \mathrm{L}$ & $0-2,3 \%$ \\
Basofil & $0-0,14 \times 10^{3} / \mu \mathrm{L}$ & $0-0,8 \%$ \\
Monosit & $0-0,34 \times 10^{3} / \mu \mathrm{L}$ & $0-1,9 \%$ \\
Rasio N/L & $0,14-0,31$ & \\
pH urin & $8-9$ & \\
Suhu badan & $37-38^{\circ} \mathrm{C}$ & \\
\hline
\end{tabular}

Analisis data. Data ditabulasi dan dianalisis secara statistik berdasarkan ANOVA, apabila terdapat perbedaan antar kelompok maka dilanjutkan dengan uji DMRT $(\mathrm{p}<0,05)$. Analisis statistik menggunakan piranti SPSS versi 16.0.

\section{HASIL}

Setelah perlakuan Penisilin dan/atau Propolis, pada tubuh hewan uji tidak ditemukan adanya urtikaria, tidak muncul indikasi reaksi alergi, hipersensitivitas, anafilaksis, maupun reaksi-reaksi imunologis 
lainnya yang menunjukkan bahwa sistem imun hewan uji merespons Penisilin dan/atau Propolis secara berlebihan. Kisaran nilai awal/normal (baseline) untuk parameterparameter yang digunakan dalam penelitian ini disajikan dalam Tabel 2. Hasil penghitungan jumlah total dan diferensial leukosit (profil leukosit), penentuan rasio $\mathrm{N} / \mathrm{L}$, pengukuran suhu badan, dan $\mathrm{pH}$ urin berturut-turut disajikan pada Gambar 1-3.

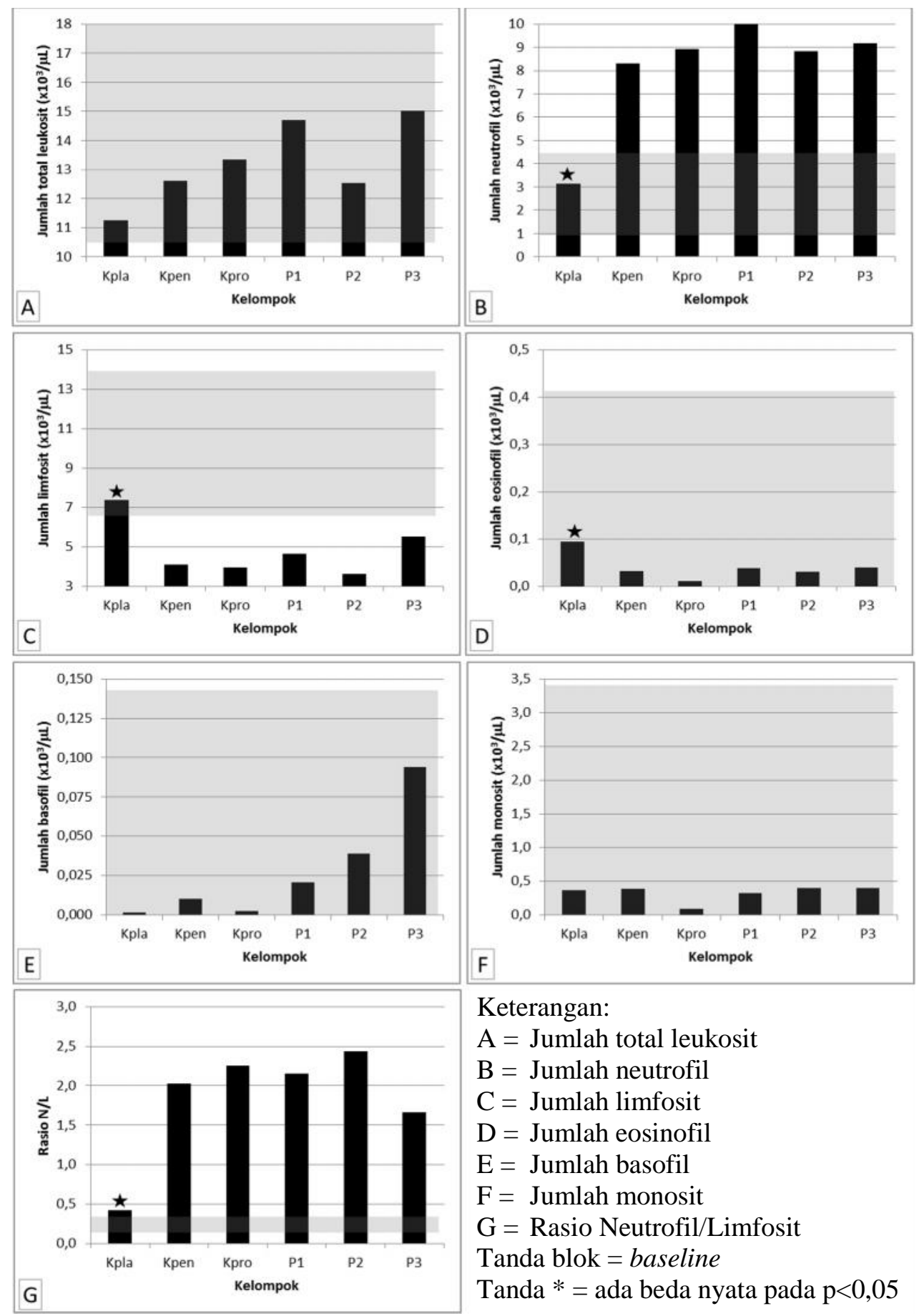

Gambar 1. Profil leukosit dalam penelitian ini

Keterangan: Kpla $=$ Kontrol plasebo, Kpen $=$ Kontrol Penisilin, Kpro $=$ Kontrol Propolis, $\mathrm{P} 1=$ Perlakuan Penisilin + Propolis 13,5 mg, P2 = Perlakuan Penisilin + Propolis 27,0 mg, P3 = Perlakuan Penisilin + Propolis 40,5 mg. Tanda blok $=$ baseline. Tanda $*=$ ada beda nyata pada $\mathrm{p}<0,05$ 


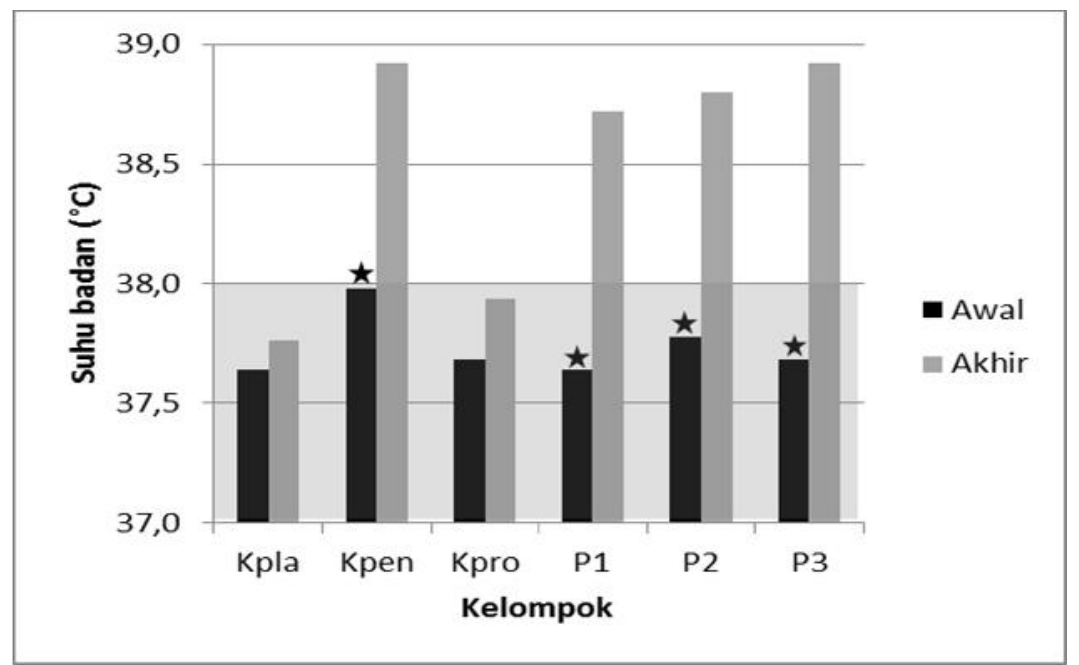

Gambar 2. Suhu badan hewan uji sebelum dan setelah penelitian

Keterangan: Kpla $=$ Kontrol plasebo, Kpen $=$ Kontrol Penisilin, Kpro $=$ Kontrol Propolis, P1 $=$ Perlakuan Penisilin + Propolis 13,5 mg, P2= Perlakuan Penisilin + Propolis 27,0 mg, P3= Perlakuan Penisilin + Propolis $40,5 \mathrm{mg}$. Tanda blok $=$ baseline. Tanda $*=$ ada beda nyata pada $\mathrm{p}<0,05$

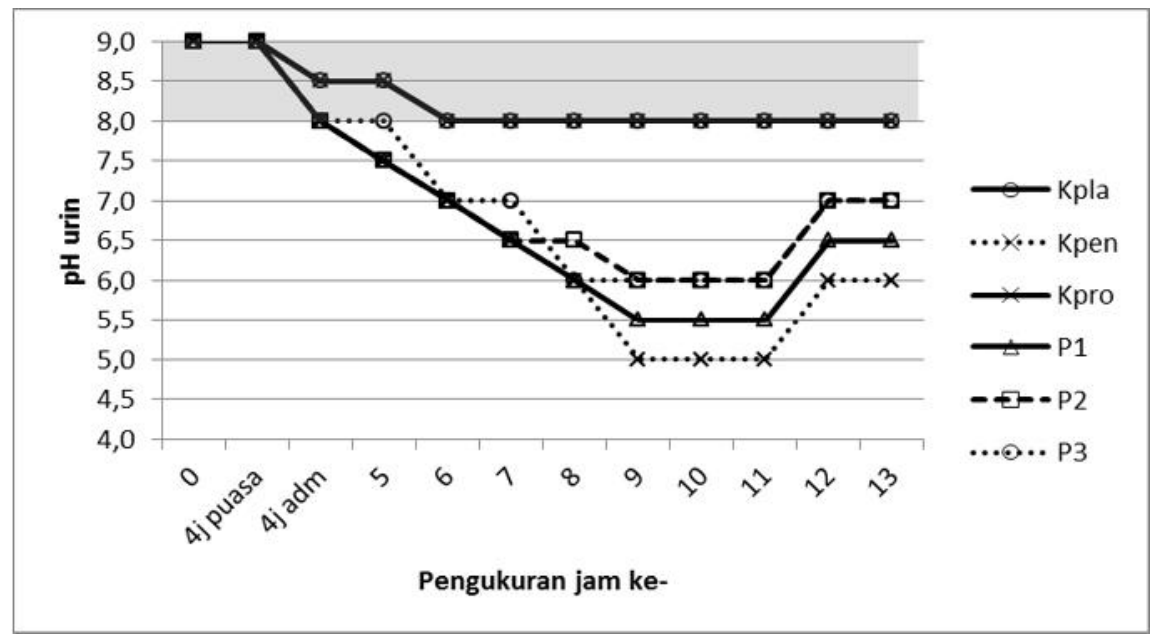

Gambar 3. pH urin hewan uji sebelum dan setelah penelitian

Keterangan: Kpla $=$ Kontrol placebo, Kpro $=$ Kontrol Propolis Kpen $=$ Kontrol Penisilin, $\mathrm{P} 1=$ Perlakuan Penisilin + Propolis 13,5 mg, P2= Perlakuan Penisilin + Propolis 27,0 mg, P3= Perlakuan Penisilin + Propolis 40,5 mg. Tanda blok = baseline .

\section{PEMBAHASAN}

Rerata jumlah total leukosit pada semua kelompok berada dalam kisaran normal (Gambar 1A). Kelompok yang diberi perlakuan Penisilin dan/atau Propolis memiliki jumlah total leukosit yang lebih tinggi daripada kontrol plasebo, namun uji statistik menunjukkan bahwa tidak ada perbedaan yang signifikan pada semua kelompok. Hal ini berarti kehadiran Penisilin dan/atau Propolis tidak menginduksi peningkatan jumlah total leukosit secara berlebihan.

Menurut Porth (2011), peningkatan jumlah leukosit (leukositosis) pada umumnya mengindikasikan adanya respons inflamasi akibat infeksi. Infeksi bakteri meningkatkan jumlah neutrofil (neutrofilia), sedangkan infeksi virus menurunkan jumlah neutrofil (neutropenia) dan meningkatkan jumlah limfosit (limfositosis). Penurunan jumlah limfosit (leukopenia) terjadi pada individu dengan infeksi berlanjut atau gangguan kemampuan produksi leukosit. Pada penelitian ini jumlah neutrofil naik secara signifikan hingga di atas kisaran normal atau terjadi neutrofilia (Gambar 1B), diikuti jumlah limfosit yang turun secara signifikan hingga di bawah kisaran normal atau terjadi leukopenia 
(Gambar 1C). Hal ini menyebabkan rasio N/L naik secara signifikan hingga di atas kisaran normal (Gambar 1G).

Menurut Zahorec (2001) dalam Çakur et al. (2015), rasio N/L merupakan parameter sederhana yang dapat menggambarkan kondisi stres fisiologis maupun respons imun. Respons imun secara umum dicirikan dengan peningkatan jumlah neutrofil dan penurunan jumlah limfosit (Jilma et al. 1999 dalam Çakur et al., 2015). Pada penelitian ini terjadi peningkatan rasio $\mathrm{N} / \mathrm{L}$ padahal tidak ada induksi bakteri atau patogen lain yang menyebabkan infeksi. Adanya peningkatan dan/ atau penurunan sel-sel imunokompeten tertentu secara signifikan tanpa adanya infeksi patogen ini diduga akibat pemberian Propolis sebagai imunomodulator. Efek imunomodulasi dapat bekerja melalui efek imunostimulasi yang menyebabkan kondisi neutrofilia (Chen et al., 2012) atau efek imunosupresi yang menghambat proliferasi limfosit sehingga menyebabkan kondisi limfopenia (Chan et al., 2013). Dalam penelitian ini ditemukan kondisi neutrofilia dan limfopenia, sehingga diduga Propolis memiliki efek imunostimulasi maupun imunosupresi.

Hasil pengamatan terhadap jenis leukosit yang lain menunjukkan bahwa jumlah eosinofil pada kelompok yang diberi perlakuan Penisilin dan/atau Propolis mengalami penurunan yang signifikan namun masih berada di dalam rentang baseline (Gambar 1D). Sebaliknya jumlah basofil pada kelompok yang diberi perlakuan Penisilin dan/atau Propolis mengalami peningkatan namun tidak signifikan (Gambar 1E). Sementara itu, jumlah monosit tidak mengalami perubahan yang signifikan dan tetap dipertahankan di dalam kisaran normal (Gambar 1F). Data ini memberikan informasi bahwa pemberian Penisilin dan/atau Propolis tidak berpengaruh terhadap ketiga jenis leukosit tersebut.

Pengukuran suhu badan. Pada semua kelompok, suhu badan setelah penelitian (4 jam) mengalami peningkatan dibandingkan sebelum penelitian. Peningkatan signifikan hingga di atas nilai baseline terdapat pada kelompok yang diberi Penisilin, baik kontrol maupun perlakuan Penisilin+Propolis. Pada beberapa individu, Penisilin memicu reaksi alergi atau hipersensitivitas. Namun demikian, dalam penelitian ini hewan uji tidak menunjukkan adanya tanda-tanda alergi, seperti peningkatan suhu badan yang disertai iritasi kulit, urtikaria, anafilaksis, dan naiknya jumlah basofil secara signifikan.

Pemberian Propolis saja tidak memicu peningkatan suhu badan secara signifikan, seperti halnya pada kontrol plasebo. Namun demikian, Propolis yang diberikan bersamasama dengan Penisilin menyebabkan peningkatan suhu badan secara signifikan (reaksi inflamasi tetap terjadi). Bahkan makin tinggi dosis Propolis yang diberikan, makin tinggi pula suhu badan hewan uji. Hal ini tidak sesuai dengan telaah oleh de Almeida and Menezes (2002) dan juga Ramos and Miranda (2007) mengenai Propolis sebagai agen antiinflamasi. Menurut Lotfy (2006), senyawa CAPE dalam Propolis menunjukkan efek antiinflamasi yang signifikan. Mekanisme aksi CAPE sebagai antiinflamasi adalah dengan cara menekan produksi IL-6 dan IL-2 yang merupakan sitokin proinflamasi, sementara itu meningkatkan produksi IL-10 yang merupakan sitokin imunotoleran (Chan et al., 2013). Barangkali dosis Propolis yang diaplikasikan dalam penelitian ini belum mampu memicu efek antiinflamasi terhadap Penisilin (perlu penelitian lebih lanjut).

Pengukuran pH urin. Derajat keasaman $(\mathrm{pH})$ urin dapt mencerminkan $\mathrm{pH}$ cairan darah, nilai normal berkisar antara 4,5-8,0. Faktor utama yang mempengaruhi $\mathrm{pH}$ urin adalah aktivitas metabolisme dan makanan yang dikonsumsi (Simerville et al., 2005). Untuk mengetahui apakah pakan yang diberikan dalam penelitian ini mempengaruhi $\mathrm{pH}$ urin, maka hewan uji dipuasakan selama 4 jam. Hasil menunjukkan (Gambar 3) bahwa sebelum puasa, pada saat puasa, dan setelah hewan uji kembali diberi makan, $\mathrm{pH}$ urin tidak berubah dari nilai baseline, yaitu 8,0-9,0. Dengan demikian, apabila selama perlakuan terjadi perubahan $\mathrm{pH}$ urin, maka hal tersebut bukan berasal dari pakan namun dari pengaruh Propolis atau Penisilin. Propolis bersifat asam $(\mathrm{pH}=6,1)$, demikian juga Penisilin-G, $\mathrm{pH}=6,0$ - 
7,5 (Plumb, 2002). Dari Gambar 3 terlihat bahwa kelompok yang diberi Propolis memiliki $\mathrm{pH}$ urin yang identik dengan kontrol plasebo, yang berarti pemberian Propolis tidak mempengaruhi $\mathrm{pH}$ urin. Sementara itu kelompok yang diberi Penisilin mengalami penurunan $\mathrm{pH}$ urin hingga mencapai 5,0 (di bawah baseline). Kelompok yang diberi perlakuan Penisilin+Propolis memiliki urin dengan $\mathrm{pH}$ rendah, namun masih lebih tinggi dibandingkan kontrol Penisilin. Disimpulkan bahwa pemberian Propolis dapat menetralisir keasaman urin akibat Penisilin. Makin tinggi dosis Propolis maka $\mathrm{pH}$ urin mendekati normal atau baseline.

Pengukuran $\mathrm{pH}$ urin bertujuan untuk mengetahui berapa lama waktu yang dibutuhkan sejak Penisilin diinjeksi hingga diekskresikan keluar tubuh melalui ginjal. Setelah 4 jam sejak injeksi Penisilin, ternyata $\mathrm{pH}$ urin hewan uji masih tinggi. Hal ini menunjukkan bahwa Penisilin masih bersirkulasi di dalam darah (Penisilin dalam urin menurunkan $\mathrm{pH}$ urin). Dengan demikian berarti respons imun yang ditunjukkan melalui uji hematologis (profil leukosit) dan pengukuran suhu badan adalah akibat dari pemberian Penisilin. Hal ini karena pada kontrol Propolis tidak terjadi peningkatan suhu badan yang signifikan sebagaimana pada kontrol Penisilin maupun perlakuan Penisilin+Propolis (Gambar 2).

Meskipun Propolis dapat memiliki efek imunostimulasi maupun imunosupresi, namun studi terbaru menunjukkan bahwa efek imunomodulasi Propolis terutama adalah melalui mekanisme imunosupresi terhadap proliferasi limfosit yang mengakibatkan berkurangnya produksi sitokin-sitokin yang bekerja sebagai imunostimulan. Efek imunosupresi Propolis meningkat seiring bertambahnya dosis (Chan et al., 2012).

Senyawa CAPE dalam Propolis menghambat proliferasi sel $\mathrm{T}$ melalui supresi produksi IL-2. Senyawa fenolik ini juga menghambat aktivitas NFAT dan NF- $\mathrm{kB}$ sehingga mengganggu aktivasi sel $\mathrm{T}$ yang berfungsi sebagai regulator atau efektor dalam sistem imun (Márquez et al., 2004; Chan et al., 2012). Senyawa lain dalam Propolis yang bekerja sebagai imunosupresor adalah Artepillin C dengan mekanisme aksi yang lebih kurang sama dengan CAPE, yaitu menekan proliferasi sel T. Senyawa ini juga bekerja dengan cara menekan proliferasi makrofag (Paulino et al., 2008 dalam Chan et al., 2012). Senyawa aktif dalam Propolis bervariasi tergantung dari wilayah dan jenis tumbuhan yang dikumpulkan oleh lebah. Artepillin C merupakan senyawa bioaktif utama di dalam propolis dari Brazil, sementara Propolis yang berasal dari wilayah Asia Pasifik (termasuk Indonesia) mengandung CAPE sebagai senyawa bioaktif utama. Propolis asal Selandia Baru diketahui memiliki kandungan CAPE terbanyak (Demestre et al., 2009; SilvaCarvalho et al., 2015).

Efek imunosupresor berperan untuk menekan respons imunologis yang berlebihan, misalnya pada saat pemberian antibiotik (Roitt et al., 2002). Dalam penelitian ini Penisilin menginduksi terjadinya demam. Namun demikian Propolis yang diberikan belum mampu memicu efek antiinflamasi terhadap Penisilin.

\section{KESIMPULAN}

Pemberian Propolis pada tikus Wistar yang diinjeksi Penisilin-G menyebabkan kondisi neutrofilia dan limfopenia, sementara itu mempertahankan jumlah sel-sel imunokompeten lainnya dalam kisaran normal. Kondisi ini menunjukkan efek imunomodulator Propolis yang diduga merupakan aktivitas senyawa Caffeic Acid Phenethyl Ester (CAPE) melalui mekanisme imunosupresi. Namun demikian, pemberian Propolis pada tikus Wistar yang diinjeksi Penisilin-G tidak menunjukkan adanya efek antiinflamasi. Oleh karena itu, penelitian lebih lanjut diperlukan untuk mendukung hasil yang diperoleh saat ini, baik kajian farmakologis maupun molekular.

\section{DAFTAR PUSTAKA}

Çakur U, Tuman TC, Yildirun O. 2015. Increased Neutrophil/Lymphocyte Ratio in Patients with Bipolar Disorder: A Preliminary Study. Psychiatria Danubina vol 27(2): 180-184. 
Carlsson HE. 2008. The Use of Laboratory Animals in Biomedical Studies. FELASA Category C-Like Course. Bogor: Pusat Studi Satwa Primata Institut Pertanian Bogor (PSSP-IPB).

Chan GC, Cheung KW, Sze DMY. 2013. The Immunomodulatory and Anticancer Properties of Propolis. Clinic Rev Allerg Immunol vol 44:262-273.

Chen MH. Lo DY, Liao JW, Hsuan SL, Chien MS, Lin CC, Chen TH, Lee WC. 2012. Immunostimulation of Sugar Cane Extract on Neutrophils to Salmonella typhimurium Infection in Mice. Phytotherapy Research vol 26(7): 10621067.

Demestre M, Messerli SM, Celli N, Shahhossini M, Kluwe L, Mautner V, Maruta H. 2009. CAPE (Caffeic Acid Phenethyl Ester)-Based Propolis Extract (Bio 30) Suppresses the Growth of Human Neurofibromatosis (NF) Tumor Xenografts in Mice. Phytotherapy Research vol 23(2):226-230.

de Almeida EC, Menezes H. 2002. Antiinflammatory Activity of Propolis Extracts: A Review. J Venom. Anim. Toxins vol 8(2): 191-212.

Fitria L, Sarto M. 2014. Profil Hematologi Tikus (Rattus norvegicus Berkenhout, 1769) Galur Wistar Jantan dan Betina Umur 4, 6, dan 8 Minggu. Biogenesis vol 2(2): 94-100.

Lotfy M. 2006. Biological Activity of Bee Propolis in Health and Disease. Asian Pacific Journal of Cancer prevention vol 7: 22-31.

Márquez N, Sancho R, Macho A, Calzado MA, Fiebich BL, Muňos E. 2004. Caffeic Acid Phenethyl Ester Inhibits T-Cell Activation by Targeting Both Nuclear Factor of Activated T-Cells and NF- $\kappa \mathrm{B}$ Transcription Factors. JPET vol 308: 9931001.

Omene C, Kalac M, Wu J, Marchi E, Frenkel K, O'Connor OA. 2013. Propolis and its
Active Component, Caffeic Acid Phenethyl Ester (CAPE), Modulate Breast Cancer Therapeutic Targets via an Epigenetically Mediated Mechanism of Action. J Cancer Sci Ther vol 5(10): 334342.

Plumb DC. 2002. Veterinary Drug Handbook. Fourth ed. Iowa: Iowa State Press.

Porth CM. 2011. Inflammation, the Inflammatory Response, and Fever: White Blood Cell Response. Essentials of Pathophysiology: Concepts of Altered Health States. $3^{\text {rd }}$ ed. Philadelphia: Wolters Klower Health/Lippincott Williams \& Wilkins.

Purwanto SL. Istiantoro Y, Kurnia Y, Sembiring SU, Effendie R. 1992. Data Obat di Indonesia: Keterangan Lengkap dari Obat-obat yang Beredar di Indonesia. Edisi 8. Jakarta: PT. Grafidian Jaya.

Ramos AFN, Miranda JL. 2007. Propolis: A Review of Its Anti-inflammatory and healing Actions. J Venom. Anim. Toxins incl. Trop. Dis. vol 13(4) 697-710.

Roitt IM, Brostoff J, Male D. 2002. Immunology. $6^{\text {th }}$ ed. Mosby: Elsevier Science Ltd. Pub. Holland.

Silva-Carvalho R, Baltazar F, Almeida-Aguiar C. 2015. Propolis: A Complex Natural Product with a Plethora of Biological Activities that can be explored for Drug Development. Review. Evid Based Complement Alternat Med. doi: 10.1155/2015/206439.

Simerville JA, Maxted WC, Pahira JJ. 2005. Urinalysis: A Comprehensive Review. Am Fam Physician vol 71: 1153-1162.

Wijayanti MA, Herdiana EM, Mardihusodo SY. 2003. Efek Bee Propolis terhadap Infeksi Plasmodium berghei pada Mencit Swiss. Berkala Ilmu Kedokteran vol 35(2): 81-89.

Yadav SK, Nagarathna PKM, Yadav CK. 2015. Research Article of Evaluation of Immunomodulatory Activity of Dalbergia latifolia on Swiss Albino Mice. IOSR$J P B S$ vol 10(3): 58-64. 